\title{
Mental Health of School Teachers In Respect Of Location, Gender, \& Stream Of Teaching in Nadia District, West Bengal
}

\author{
Partha Sarathi Panda ${ }^{1} \&$ Anujit Patra ${ }^{2 *}$ \\ ${ }^{I}$ Assitant Professor, Radharani Educational Institute, Bankura, W. B., India. \\ ${ }^{2}$ Assistant Professor, Ratulia Secondary Teachers' Training Institute, Purba Medinipur, W. B., India.
}

\begin{abstract}
One of the important merits in the teacher is that he knows his subject thoroughly well and is to keep in touch with his subject to remain up-to-date. A good teacher is required to have an attitude of love and sympathy for children. The ideal character of teacher leaves an ever lasting impression on the minds of his pupil. It is the teacher who can create a national perspective for understanding social and economic difference in the nation. The teacher should be a model to his own image in the minds of his students. The present study seeks to compare the mental health of secondary school teachers in respect of their location, gender and stream of teaching. Twenty school teachers chosen from Krishnanagar-II, block of Nadia district of West Bengal as sample. RCE mental health scale by Anand (1992) has been adopted by present researchers. Study revealed that, teachers' mental health was not changeable in respect of their location, gender and stream of teaching. More research also needed to identify the specific factors by which, mental health of school teachers will reflect efficiently.
\end{abstract}

Key words: Mental health, School teacher, Gender, Locale, Stream.

\section{INTRODUCTION}

In contemporary period, problems have also multiplied in proportion to quick development in all walks of life. In ancient India, when education was restricted to privileged communities, teaching was entrusted to great scholars and concerned no problem. With the pass of time, education ruined the barriers of caste and community and reached the masses. This new movement of mass education is troubled with certain problems for teachers. Good mental health can be achieved by following the principle of mental hygiene, which is the science of the investigation and application of those measures that prevent mental disorder. Mental health is a way of living satisfactorily and effectively with other members of the society [1]. The level of mental health of teacher can affect his working as well as his organizational climate. If teacher don't enjoy sound mental health, they cannot concentrate in teaching and retain the knowledge given to the students. Also, he cannot have a proper and well-adjusted personality. So, teacher's mental health plays an important role in teaching and learning process. The sound mental health is important to each and every person. It is generally believed that health and physical fitness are ideals about realization of which man has been determined for generations. So, the sound mental health of the person is important for those who (teacher) work for the development of the nation. The teachers are just like the main wheels on whose shoulders stand the Professional concern with the job, has powerfully undergone a change which adversely affects the mental health of the teacher. According to [2] mental health is a situation of psychological maturity. It is a condition of personal and social performance with a maximum of effectiveness and satisfaction. Mental health involves positive judgment and attitudes towards the self and others also.

Mental health is an indispensable component of the overall health of a teacher. In fact, a healthy teacher is one who can guide himself in a coordinated mode with external situations. [3] did an investigation on mental health of female teachers with regard to location and management in Bongaigaon district of Assam. The study revealed significant difference between urban and rural teachers. Study also explored that, the mental health of the urban teachers was better than the rural teachers. [4] found significantly better mental health as compared to their female colleagues. It also concluded that, gender differences in mental health status could be that female teachers experience the burden of dual responsibilities - home and work, leading to greater stress and hence poorer mental health. [5] conducted a study to know the impact of mental health on the level of burnout of the teachers teaching at different educational level. They concluded that teachers with low mental health are more prone to burnouts than the teachers of average and high mental health. [6] revealed low score in mental health of female teachers, as compared to male teachers. Female teachers work more in maintaining households, raising family, caring out economically productive activities in marketing and so they work more hours than do their husbands. [7] found positive relationship between mental health and job satisfaction of primary school teachers. They also revealed insignificant differences between male and female teachers mental 
health. [8] conducted a comparative study on adjustment and mental health of public school teacher and govt. school teacher. They found significant difference in mean score of female teachers than male teachers in respect of their mental health. [9] did an investigation on mental health of secondary school teachers of Sikkim. Study found, significant difference between male and female secondary teachers concerning with mental health. Similarly educational qualifications and management variation of the schools were. But mental health of the teachers was not influenced by their teaching experience. [10] conducted a survey on analysis and maintenance of mental health of female teachers in colleges of china. Most of the female teachers were in a dilemma of how to perform and synchronize the social and family responsibilities well, which has been a heavy trouble on their mental and physical health. Teachers mental health positively correlated with their job satisfaction in govt. aided and sponsored schools of West Bengal [11]. There have been many studies conducted on mental health of teachers in relation to different variations i.e. living area, gender, management of schools, experiences, educational qualifications, etc. But in West Bengal, such type of research were very few in number and in the district Nadia, specific survey was rarely done.

\subsection{Objectives}

1. To study the mental health of school teachers in respect of locale (rural \& urban).

2. To study the mental health of school teachers in respect of gender (male \& female).

3. To study the mental health of secondary school teachers in respect of stream of teaching (arts \& sciences).

\subsection{Hypotheses}

$\mathrm{H}_{0} 1$ : There is no significant difference between rural and urban school teachers in respect of mental health.

$\mathrm{H}_{0}$ 2: There is no significant difference between male and female school teachers in respect of mental health.

$\mathrm{H}_{0} 3$ : There is no significant difference between Arts and Science teachers in respect of mental health.

\section{METHODS}

This was a survey type research, where researchers tried to focus all the school teachers teaching in secondary schools of Krishnanagar- II, Block, Nadia District, India. Randomly twenty teachers were selected as sample. Researchers has used R.C.E. Mental Health Scale [12], consisted with 60 items (5 point Likart Type) for collecting of data. Descriptive and inferential statistics were used for analysis of data.

\section{RESULTS}

The most important part of any research is the analysis and interpretation of the data. This section deals with analysis and interpretation of the data collected through tools employed in the study by the investigators.

Table 1; t-test of Mental Health of teachers in respect of location variation.

\begin{tabular}{|c|c|c|c|c|c|c|}
\hline \multicolumn{2}{|c|}{ Variance } & Mean & df & t- value & P-value & Remarks \\
\hline \multirow{2}{*}{ Locale } & Rural & 204.1 & \multirow{2}{*}{18} & 0.24 & 0.81 & Significant* \\
\cline { 2 - 3 } & Urban & 202.5 & & & & \\
\hline
\end{tabular}

$* 0.05$ level (two tailed)

In the above (Table 1) the researchers found that the Mean value of the rural teachers $(\mathrm{M}=204.1)$ was higher than the urban teachers $(\mathrm{M}=202.5)$. In this table probability value $(\mathrm{P}$, two-tail) was 0.81 , which was greater than alpha lavel 0.05 . As a result insignificant difference in mental health was found between rural and urban teachers. Hence, the null hypothesis $\left(\mathrm{H}_{0} 1\right)$ was not rejected.

Table 2; t-test of Mental Health of school teachers in respect of gender variation.

\begin{tabular}{|c|c|c|c|c|c|c|}
\hline \multicolumn{2}{|c|}{ Variance } & Mean & df & t-value & P-value & Remarks \\
\hline \multirow{2}{*}{ Gender } & Male & 201.5 & 18 & -0.55 & 0.59 & Significant* \\
\cline { 2 - 3 } & Female & 205.1 & & & & \\
\hline
\end{tabular}

$* 0.05$ level (two tailed)

Here researchers found that the Mean value of the male teachers $(M=205.1)$ was more, than the female teachers $(M=201.5)$ in secondary school. From the above (Table 2) the researchers also found the probability value (P, two-tail) was 0.59 , which was greater than alpha value 0.05 level. That means insignificant difference existed between male and female teachers' mental health. Hence, the null hypothesis $\left(\mathrm{H}_{0} 2\right)$ was not rejected. 
Table 3; t-test of Mental Health of school teacher in respect of stream of teaching variation.

\begin{tabular}{|c|c|c|c|c|c|c|}
\hline \multicolumn{2}{|c|}{ Variance } & Mean & df & t & P & Remarks \\
\hline $\begin{array}{c}\text { Stream of } \\
\text { teaching }\end{array}$ & Arts & 204.1 & 18 & 0.37 & 0.72 & Significant* \\
\cline { 2 - 3 } & Science & 202.5 & & & & \\
\hline
\end{tabular}

Here researchers found that the Mean value of the Arts $(M=204.5)$ teachers was higher, than the science $(M=202.1)$ teachers in secondary school. From the above (Table 3) the researchers also found the probability value $(\mathrm{P}$, two-tail) was 0.72 , which was greater than alpha value 0.05 level. That means insignificant difference existed between Arts and Science teachers' mental health. Hence, the null hypothesis $\left(\mathrm{H}_{0} 3\right)$ was not rejected.

\section{DISCUSSION}

The acceptance of hypothesis on the basis of t-test signifies that mental health of secondary school teacher was not differed in respect of teachers' location i.e. rural and urban situations. The result is consistent with previous research [13], [14]. The present research was inconformity of the earlier study by [3] revealed significant difference between urban and rural teachers. They also explored that, the mental health of the urban teachers was better than the rural teachers. Acceptance of the hypothesis on the basis of t-test signifies that mental health of teachers was not differed in respect of gender variations. The findings supported by the study of [7], [9], [13], \& [14]. But significant difference was found by [8].

Mental health of the school teachers was not changeable with different stream of teaching i.e. arts and science. The result is supported by [15], \& [16].

\section{CONCLUSION}

On the basis of results reported above, it can be concluded that, location, gender and stream of teaching has no effect on the mental health of Bengali medium secondary school teachers in Nadia district of West Bengal. Special measures should be considered for better and effective teaching learning purposes. Throughout all the variations (i.e. locale, gender \& stream of teaching) mental health of teachers in Krishnanagar II block was good. To enhance the mental health of school teachers to the highest level on class room oriented attitude, school authorities have to implant the values like co-operation, fellow feelings, sympathy, etc. This may useful for teachers, administrators, educational planners and concerned authorities in making the teaching-learning process more effective. More research also needed to identify the specific factors by which, mental health of school teachers will reflect efficiently.

\section{ACKNOWLEDGEMENT}

Authors thankful to Dr. Abhijit Guha, Associate Professor, Ramakrishna Mission Sikshanamandir, Belur Math, Howrah, W. B. India, for his advice during this study.

\section{REFERENCES}

[1] Das, C. (2008). Need for health education in the 21 st century with special reference to reproduction health of adolescents. Journal of Community Guidance and Research, 25(2).

[2] Chauhan, S. S. (2011). Mental hygiene: A science of adjustment (2 ${ }^{\text {nd }}$ Ed.). New Delhi. Allied Pub. Pvt. Ltd. 307- 315.

[3] Baro, S. D. (2014). A study on mental health of female teachers with regard to location and management in Bongaigaon district of Assam. The International Journal of Humanities \& Social Studies. 2(9), 149155. Retrieved from www.theijhss.com

[4] Basu, S. (2009). Mental health status of college teachers. Praachi Journal of Psycho-Cultural Dimentions. ISSN 0971 7064. 25 (1 \& 2). 168-170.

[5] Srivastava, B., \& Khan, S. (2008). Teacher-burnout in relation to mental health. Edutracks. 7(9).

[6] Dewan, R., Hassan, M. K, \& Sing, A. R. (2009). Effects of demographic variables on mental health of tribal school teachers. Praachi Journal of Psycho-Cultural Dimentions. ISSN 0971 7064. 25 (1 \& 2). 162167.

[7] Baro, S. D., \& Panda, B. B. (2014). Relationship between mental health and job satisfaction among primary school teachers: a study with special reference to Bongaigaon district of Assam. Abhinav

National Monthly Refereed Journal of Research in Commerce \& Management. 3(8). 15-25. Retrieved from www.abhinavjournal.com

[8] Gangwar, P., \& Singh, P. ( 2004). A comparative study of adjustment and mental health of public school teacher and govt. school teacher. Retrieved from docshare04. docshare.tips/files/8935/89350448.pdf 
[9] Pradhan, R. (2016). Mental health of secondary school teachers in Sikkim. IOSR Journal of Humanities and Social Science. 21 (11). 50-57. Retrieved from www.iosrjournals.org

[10] Yin-Ling, Z. (2006). Analysis and maintenance of mental health of female teachers in College of China. U.S- China Education Review, U.S.A., 3(8).

[11] Behera, D. (2014). Relationship between job satisfaction and mental health of mainstream school teachers in West Bengal. International Journal of Scientific research. 3 (8). 79-84. Retrieved from www.worldwidejournals.com

[12] Anand, S.P. (1992) RCE Mental Health Scale (Bengali version by B. P. Nanda).

[13] Kaur, S., Niwas, R., \& RAi, V. (2015). A study of mental health of high school students in relation to sex and habitation. Scholarly Research Journal for Humanity Science \& Englih Language. 2 (12). 31703177. Retrieved from www.srjis.com

[14] Kumar, V., Kumar, P., \& Kumari, R. (2013). Study of mental health of pupil teachers in relation to their gender and locality. International Monthly Refereed Journal of Research in Management \& Technology. Vol. III, 104- 110

[15] Sharma, U. (2015). A study of mental health of pupil teachers in relation to their attitude towards teaching profession. International Journal of Applied Research. 1 (7), 344-348. Retrieved from www. allresearchjournal.com.

[16] Johal, S.K., \& Pooja. (2016). Relationship between mental health and psychological well being of prospective female teachers. IOSR Journal of Research \& Method in Education. 6 (1/ II), 1-6. Retrieved from www.iosrjournals.org 